\title{
Seasonal Incidence of Mealybug, Maconellicoccus hirsutus (Green) on Grape
}

\author{
A. Raghuraman Angu ${ }^{1}$, C. Narendra Reddy ${ }^{1}$, D. Anitha Kumari ${ }^{2}$ and S. Ramesh ${ }^{1 *}$ \\ ${ }^{1}$ Department of Entomology, College of Agriculture, Rajendranagar, \\ PJTSAU, Hyderabad-30, Telangana, India \\ ${ }^{2}$ Department of Entomology, Vegetable Research Station, Rajendranagar, \\ SKLTSHU, Hyderabad-30, Telangana, India \\ *Corresponding author
}

\section{A B S T R A C T}

\section{Keywords}

Grapevine mealy bug, Correlations and seasonal incidence.

\section{Article Info}

Accepted: 24 January 2017 Available Online: 10 February 2017
A field experiment to study the seasonal incidence of mealybug on grapevine was conducted at Grape Research Station, Rajendranagar, Hyderabad from July, 2014 to March, 2015. Studies on seasonal incidence of mealybug of grapevine in relation to abiotic factors were carried out during 2014-15 (July to March). The incidence of mealybug on grapevine started increasing from the first standard week of January 2015 and continued to increase thereafter till the end of the season up to harvesting of bunches. Higher incidence of mealybug colonies coincided with the fruiting stage and mealybugs were observed on the bark also. Correlation studies of mealybug population with weather parameters indicated that weather had a substantial influence on its incidence. Among the various weather parameters, morning relative humidity $(\mathrm{r}=-0.6500 * * *)$ and evening relative humidity $(\mathrm{r}=-0.5429 * * *)$ had maximum impact (significant and negative, $\mathrm{p}<0.001$ ) on mealybug incidence. Maximum temperature $(\mathrm{r}=+0.4074 *)$ and sunshine hours $(\mathrm{r}=$ $\left.+0.3445^{*}\right)$ had significant $(\mathrm{p}<0.05)$ positive influence on the pest. The other factors did not influence pest incidence significantly. This explains the higher incidence levels in summer months when relative humidity is very low, maximum temperature and sunshine hours are higher. However mealybug incidence correlated negatively and nonsignificantly with minimum temperature $(r=-0.0485)$, rainfall $(r=-0.1130)$ and wind $\operatorname{speed}(\mathrm{r}=-0.2256)$.

\section{Introduction}

Grape (Vitis vinifera) is grown under a variety of soil and climatic conditions in three distinct agro-climatic zones, namely, sub-tropical, hot tropical and mild tropical climatic regions in India. Grapes are a non-climacteric type of fruit, which can be eaten raw or they can be used for making wine, jam, juice, jelly, grape seed extract, raisins, vinegar and grape seed oil. Insect pests are the important production constraints in grape cultivation apart from diseases. In grape, 94 insect pests have been reported by Tandon and Verghese (1994). Among them, thrips, mites and mealybugs are important sucking pests causing serious damage to the vineyards. Mani et al (2008) reported that among the mealybug species infesting grapes in India, the pink mealybug Maconellicoccus hirsutus, citrus mealybug Planococcus citri, spherical mealybug Nipaecoccus viridis and striped mealybug Ferrisia virigata cause severe losses in many grape growing areas of Maharashtra, 
Karnataka, Andhra Pradesh and Tamil Nadu. First occurrence of $M$. hirsutus on grapevine has been reported by Fletcher (1919). Severe outbreak of mealybugs was reported during 1974 in Andhra Pradesh by Tejkumar et al (1977) and subsequently in several other places. Mani (1989) also reported that the population of the mealybug was found to be high from January to May and low from June to December in vineyards of South India. Babu and Azam (1989) reported that the grapevine mealybug, $M$. hirsutus is a serious vineyard pest in India. The infestation is becoming more severe every year. Heavily infested clusters shrivel and drop or become sticky and unfit for consumption. In case of severe attack in the main field upto 90 per cent clusters are damaged. After pruning the mealybug attacks tender developing sprouts causing stunted growth. Malformation of growing shoots and leaves occurs due to its feeding and sticky honeydew excreted by mealybug predisposes mould growth (Capnodium sp.). According to Murthy and Babu (1996), highest population was found on grapes during the first half of July (vegetative phase) and during the second half of March (reproductive phase) in Andhra Pradesh. Although occurrence of grape mealybug has been reported from Andhra Pradesh, comprehensive information regarding seasonal incidence of grape mealy bug and its interaction with weather parameters will help to adopt control measures in time and suppress before it cause economic damage. Hence, a study was conducted to know the seasonal incidence of grape mealy bug and influence of weather parameters on the incidence of mealy bugs.

\section{Materials and Methods}

Studies on seasonal incidence and management of grapevine mealybug Maconellicoccus hirsutus (Green) were carried out in the experimental plot at Grape
Research Station, Rajendranagar, Hyderabad, Telangana during 2014-15. Ten year old grape vineyard (Variety: Thompson seedless) was selected for studying the seasonal incidence and population dynamics of $M$. hirsutus. The crop was pruned in April (forward pruning) and October (backward pruning) and all other recommended package of practices was followed. The crop was kept free from insecticidal applications during the period of study. Fifteen vines were selected randomly and tagged. Observations on numbers of colonies were taken on various parts like stems, barks, leaves and fruits in each vine were counted and the average was worked out at weekly intervals. Seasonal incidence and peak periods of infestation were documented by collecting the absolute counts of the mealybug colonies at weekly intervals from July to March. Mealybug populations were correlated with weather parameters viz., maximum temperature, minimum temperature, morning and evening relative humidity, rainfall, sunshine and wind velocity to quantify the impact of abiotic factors on their incidence levels.

\section{Results and Discussion}

The data of the pest incidence and weekly averages of meteorological parameters are presented in table 1. Mealybug colonies were recorded at weekly intervals commencing from July, 2014 to March, 2015. Results pertaining to the studies on the seasonal incidence of grape mealybug observed during different standard weeks (Table 1 and Figure 1) indicated that the population of mealybug on grapevine started increasing from the first standard week (January 2015) and a continuous increasing trend was observed till the thirteenth standard week (March 2015) with a population of 48.33 colonies per vine. Thereafter, the population increased till the harvest of berries. Lowest population was recorded during the twenty ninth standard 
weeks (July 2014) with about 0.8 colonies per vine. Results of the present investigation indicated that the population of mealybug, $M$. hirsutus on grapevine was less from July to January second week. These findings are in accordance with those of Mani and Thontadarya (1987) who reported that the population of the mealybug, $M$. hirsutus was found to be high from January to May and low from June to December in vineyards in South India. In the present study rainfall was found to have a negative impact on the pest which was in partial agreement with GarciaÁlvarez et al., (2014) who recorded that populations of pink hibiscus mealybug, $M$. hirsutus (Green) were lower during the rainfall months from August to October and population was moderate during periods of low temperatures from November to February.

The population of mealybug on grapevine started increasing from third standard week of January 2015 and peak incidence was recorded from ninth standard week of February 2015 to thirteenth standard week of March 2015. This outcome is in close agreement with the findings of Balikai (1999) who recorded that mealybug population started to increase from January and peak infestation was observed during FebruaryMarch before harvesting. After harvest, the population remained low from May to December which was in conformity with Manjunath (1985) who reported that peak infestation was observed during FebruaryMarch and to a lesser extent during OctoberNovember.

Higher incidence of mealybug was recorded from ninth standard week of February 2015 (31.8 colonies per vine) to thirteenth standard week of March 2015 (48.33 colonies per vine). The findings are in close agreement with Maheshkumar et al., (2009) who reported that peak populations of 32.4 colonies per vine were observed during $10^{\text {th }}$ standard week in the fruiting season respectively. Similar results were also found by Kulkarni et al., (2008) who reported that mealybug population was distributed sporadically and the highest population during the last week of February to the last week of March coincided with the fruiting and harvesting season correlation co-efficient of maximum and minimum temperature, morning and evening relative humidity, sunshine hour, evaporation and rainfall against mean population of mealy bug were worked out and presented in table 2. The correlation between mealybug colonies and different weather parameters is given in the figure 2 .

Results revealed that mealybugs were profoundly affected by weather factors. It was found that out of all weather factors, relative humidity (morning and evening) had substantial negative effect on its incidence (morning relative humidity $\mathrm{r}=-0.6500 * * *$ and evening relative humidity $\mathrm{r}=-0.5429 * * *$ ) ( $\mathrm{p}<0.001)$. Mealybug incidence had a significant and positive correlation with maximum temperature $\left(\mathrm{r}=0.4074^{*}\right)$ and sunshine $\left(\mathrm{r}=0.3445^{*}\right) \quad(\mathrm{p}<0.05)$. It had nonsignificant negative correlation with minimum temperature $(\mathrm{r}=-0.0485)$, rainfall $(\mathrm{r}=-0.1130)$ and wind speed $(\mathrm{r}=-0.2256)$.

Correlation studies for relative humidity indicated that the evening and morning relative humidity showed significant negative correlation with population of mealybug. Similar findings were also registered by Koli (2003) who reported that mealybugs on grapes showed highly significant negative correlation with morning and evening relative humidity. The findings are also in agreement with Mani and Thontadarya (1987) who reported that relative humidity showed a significant negative correlation with mealybug population. 
Table.1 Seasonal incidence of grapevine mealybug, Maconellicoccus hirsutus with weather parameters (2014 - 2015)

\begin{tabular}{|c|c|c|c|c|c|c|c|c|c|}
\hline $\begin{array}{l}\text { Standard } \\
\text { week }\end{array}$ & Month and Date & $\begin{array}{l}\text { Average no. } \\
\text { of mealybug } \\
\text { colonies per } \\
\text { vine }\end{array}$ & $\begin{array}{l}\text { Maximum } \\
\text { Temperature } \\
\left({ }^{\circ} \mathrm{C}\right)\end{array}$ & $\begin{array}{l}\text { Minimum } \\
\text { Temperature } \\
\left({ }^{\circ} \mathrm{C}\right)\end{array}$ & $\begin{array}{l}\text { Relative } \\
\text { humidity } \\
\text { I } \\
(\%)\end{array}$ & $\begin{array}{l}\text { Relative } \\
\text { Humidity } \\
\text { II } \\
(\%) \\
\end{array}$ & $\begin{array}{l}\text { Rainfall } \\
(\mathrm{mm})\end{array}$ & $\begin{array}{l}\text { Sunshine } \\
\text { (hrs) }\end{array}$ & $\begin{array}{l}\text { Wind } \\
\text { speed } \\
(\mathrm{Kmph})\end{array}$ \\
\hline 29 & Jul 16-22 & 0.80 & 29.70 & 23.70 & 68.70 & 68.70 & 11.30 & 1.0 & 14.4 \\
\hline 30 & Jul 23-29 & 5.74 & 30.70 & 23.20 & 65.60 & 64.90 & 17.10 & 3.8 & 12.5 \\
\hline 31 & Aug 30-05 & 6.50 & 30.40 & 22.20 & 84.90 & 63.70 & 3.00 & 2.7 & 12.5 \\
\hline 32 & Aug 06-12 & 6.73 & 32.00 & 22.70 & 83.10 & 61.00 & 8.60 & 7.0 & 11.6 \\
\hline 33 & Aug 13-19 & 5.40 & 33.30 & 24.50 & 81.40 & 53.00 & 25.50 & 6.4 & 6.6 \\
\hline 34 & Aug 20-26 & 7.26 & 34.00 & 24.00 & 88.60 & 58.60 & 12.20 & 6.8 & 1.9 \\
\hline 35 & Sep 27-02 & 3.93 & 28.10 & 22.10 & 92.60 & 80.70 & 160.60 & 1.5 & 6.0 \\
\hline 36 & Sep 03-09 & 2.26 & 27.50 & 22.60 & 86.00 & 66.40 & 12.20 & 5.1 & 8.2 \\
\hline 37 & Sep 10-16 & 4.20 & 31.00 & 22.80 & 87.00 & 62.00 & 12.60 & 5.8 & 5.4 \\
\hline 38 & Sep 17-23 & 2.80 & 31.10 & 22.20 & 90.00 & 63.00 & 9.40 & 4.2 & 3.8 \\
\hline 39 & Sep 24-30 & 2.13 & 32.30 & 22.10 & 86.00 & 51.00 & 15.00 & 6.4 & 2.0 \\
\hline 40 & Oct 01-07 & 1.60 & 34.10 & 21.90 & 80.00 & 45.00 & 40.20 & 7.6 & 1.3 \\
\hline 41 & Oct $08-14$ & 2.52 & 32.40 & 20.30 & 78.00 & 49.00 & 0.80 & 4.3 & 3.9 \\
\hline 42 & Oct $15-21$ & 3.00 & 32.80 & 19.20 & 85.00 & 47.00 & 6.20 & 8.2 & 2.5 \\
\hline 43 & Oct $22-28$ & 2.20 & 28.30 & 19.00 & 89.00 & 68.00 & 22.00 & 4.0 & 2.0 \\
\hline 44 & Nov 29-04 & 2.60 & 30.40 & 18.40 & 80.00 & 24.00 & 0.00 & 8.3 & 2.3 \\
\hline 45 & Nov $05-11$ & 2.80 & 30.90 & 16.40 & 76.00 & 42.00 & 0.00 & 6.8 & 2.3 \\
\hline 46 & Nov $12-18$ & 2.67 & 30.00 & 19.70 & 81.00 & 61.00 & 10.60 & 5.5 & 1.8 \\
\hline 47 & Nov 19-25 & 1.86 & 30.60 & 16.40 & 87.00 & 42.00 & 0.00 & 7.6 & 1.2 \\
\hline 48 & Dec 26-02 & 2.40 & 30.60 & 12.10 & 73.00 & 3000 & 0.00 & 8.5 & 1.7 \\
\hline 49 & Dec 03-09 & 1.53 & 30.50 & 12.00 & 81.00 & 42.00 & 0.00 & 8.8 & 1.6 \\
\hline 50 & Dec 10-16 & 2.46 & 28.20 & 15.90 & 89.00 & 68.00 & 0.00 & 3.4 & 1.5 \\
\hline 51 & Dec $17-23$ & 3.06 & 27.10 & 9.30 & 71.00 & 41.00 & 0.00 & 7.7 & 1.8 \\
\hline 52 & Dec 24-31 & 4.46 & 27.1 & 11.40 & 69.00 & 47.00 & 0.00 & 8.1 & 1.5 \\
\hline 1 & Jan 01-06 & 3.26 & 29.20 & 17.90 & 78.50 & 48.80 & 0.00 & 5.7 & 1.6 \\
\hline 2 & Jan 07-14 & 4.86 & 27.10 & 5.40 & 66.00 & 23.00 & 0.00 & 9.8 & 1.3 \\
\hline 3 & Jan $15-21$ & 12.66 & 28.20 & 9.10 & 75.00 & 32.00 & 0.00 & 9.2 & 1.6 \\
\hline 4 & Jan 22-28 & 16.40 & 29.40 & 10.60 & 79.00 & 30.00 & 0.00 & 9.1 & 2.5 \\
\hline 5 & $\begin{array}{c}\text { Jan 29-04 } \\
\text { Feb }\end{array}$ & 17.20 & 28.80 & 13.30 & 86.00 & 36.00 & 0.00 & 9.3 & 2.3 \\
\hline 6 & Feb 05-11 & 17.93 & 30.70 & 13.40 & 74.00 & 26.00 & 0.00 & 9.9 & 3.2 \\
\hline 7 & Feb 12-18 & 20.20 & 33.10 & 15.00 & 66.000 & 18.00 & 0.00 & 10.2 & 1.2 \\
\hline 8 & Feb 19-25 & 26.60 & 33.30 & 16.90 & 63.00 & 21.00 & 0.00 & 9.8 & 2.0 \\
\hline 9 & $\begin{array}{c}\text { Feb 26-04 } \\
\text { Mar }\end{array}$ & 31.80 & 32.70 & 17.70 & 73.00 & 32.00 & 8.00 & 7.8 & 2.4 \\
\hline 10 & Mar 05-11 & 37.73 & 31.10 & 19.20 & 73.00 & 48.00 & 21.60 & 5.5 & 1.7 \\
\hline 11 & Mar 12-18 & 43.80 & 34.00 & 18.60 & 64.00 & 22.00 & 0.00 & 9.5 & 2.7 \\
\hline 12 & Mar 19-25 & 45.46 & 36.60 & 20.20 & 55.00 & 26.00 & 0.00 & 8.3 & 1.8 \\
\hline 13 & $\begin{array}{c}\text { Mar 26-01 } \\
\text { Apr }\end{array}$ & 48.33 & 30.00 & 18.70 & 57.00 & 29.00 & 12.00 & 6.6 & 1.3 \\
\hline
\end{tabular}


Table.2 Correlation between incidence of grapevine mealybug, Maconellicoccu hirsutus and weather parameters

\begin{tabular}{|l|c|}
\hline Weather parameters & Correlation coefficient (r) \\
\hline Maximum temperature (T max) & $+0.4074^{*}$ \\
\hline Minimum temperature (T min) & $-0.0485 \mathrm{NS}$ \\
\hline Relative humidity morning (RH I) & $-0.6500^{* * *}$ \\
\hline Relative humidity evening (RH II) & $-0.5429^{* * *}$ \\
\hline Rainfall & $-0.1130 \mathrm{NS}$ \\
\hline Sunshine & $+0.3445^{*}$ \\
\hline Wind speed & $-0.2256 \mathrm{NS}$ \\
\hline$* *$ = Significant at $0.1 \% ; *$ Significant at 5\%; NS = Non significant
\end{tabular}

Fig.1 Seasonal incidence of mealybug, Maconellicoccus hirsutus on grapevine (July 2014 to March 2015)

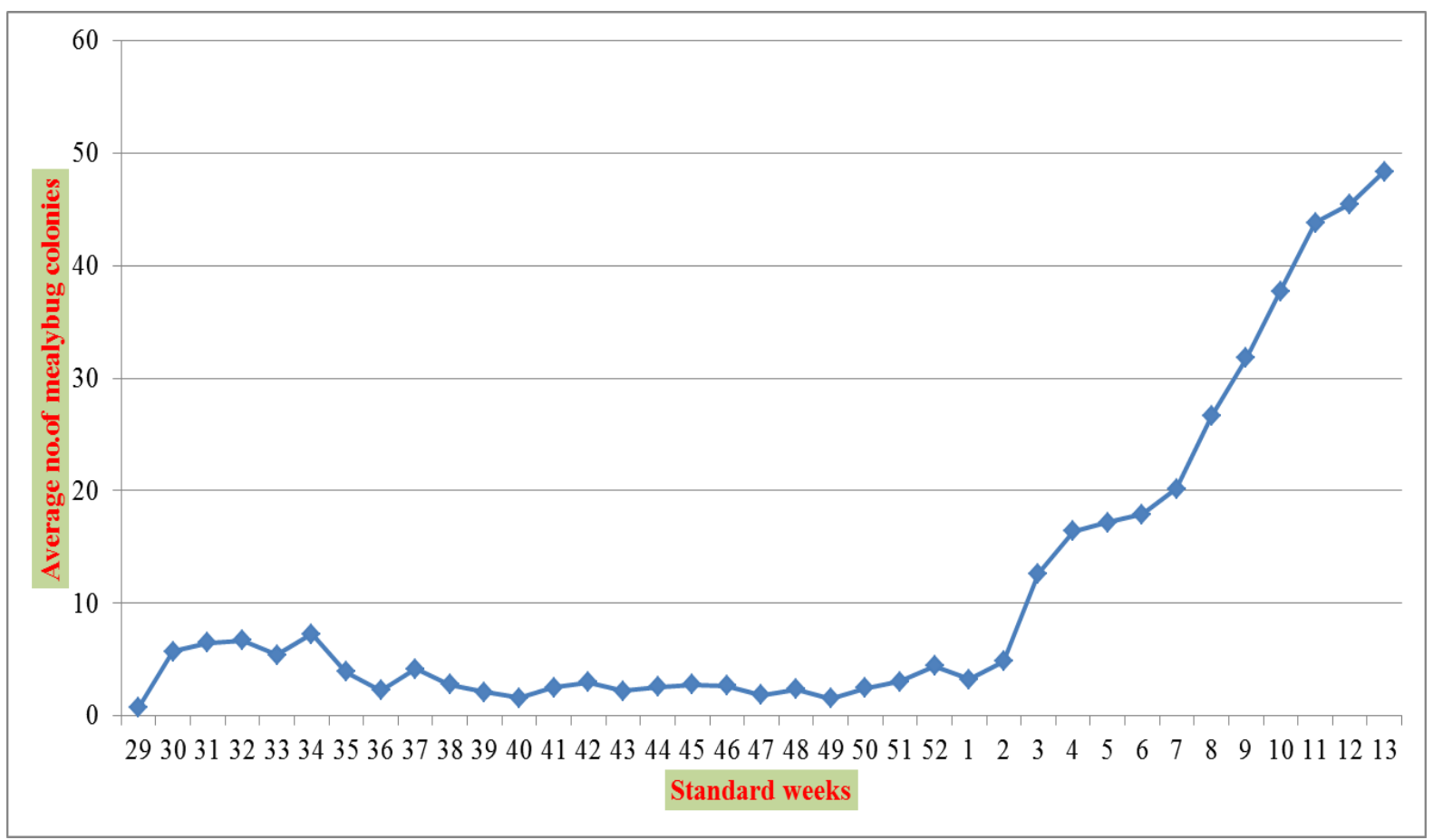


Fig.2 Correlation of incidence of grapevine mealybug, Maconellicoccus hirsutus with different weather parameters
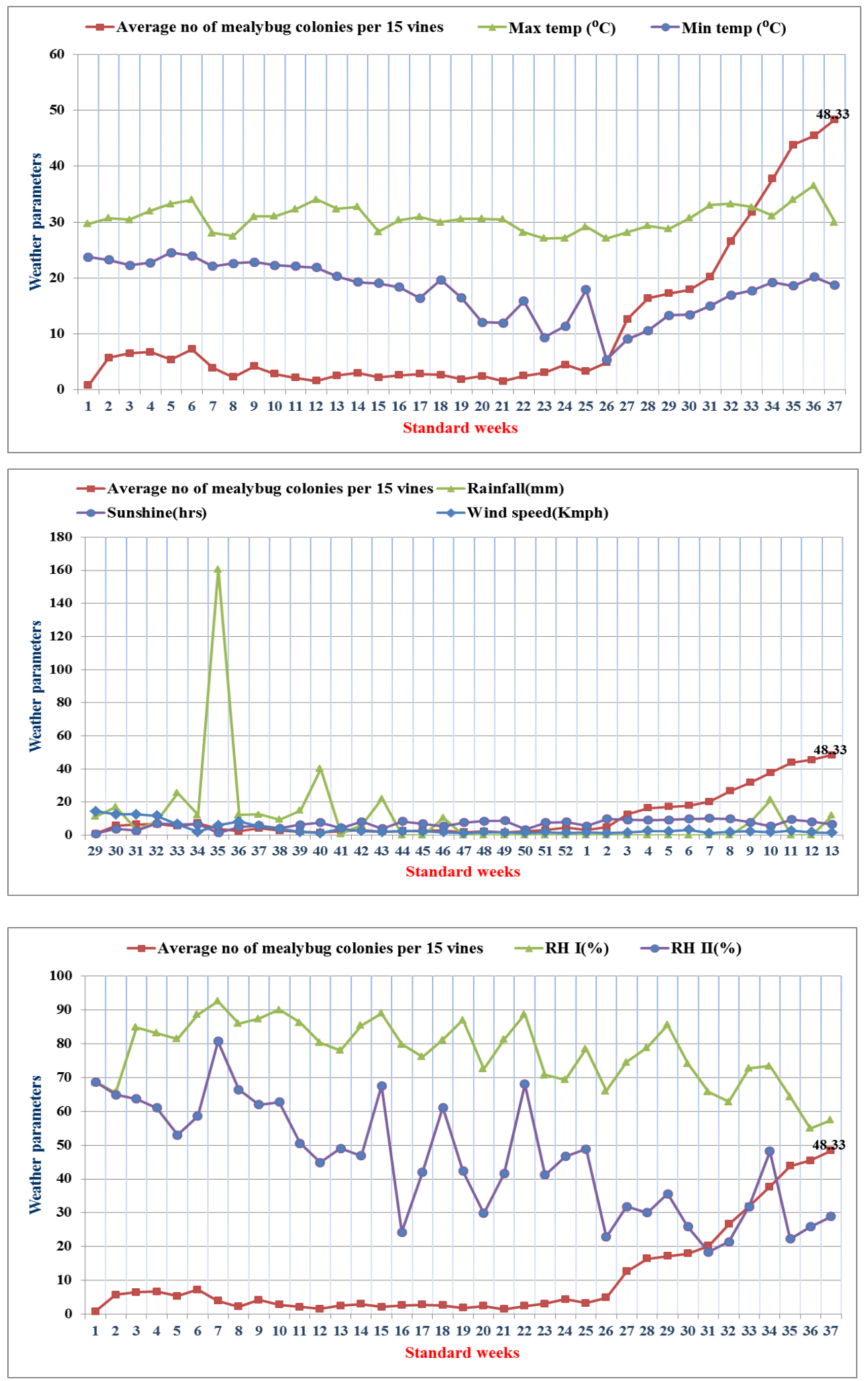
Significant positive correlation was observed between population of mealybug and maximum temperature and sunshine hours in the present study. These findings are in conformity with those of Mani and Thontadarya (1987) who reported that maximum temperature showed a positive and significant correlation with the mealybug population. Further, the findings are also in partial agreement with Koli (2003) who opined that mealybugs on grapes showed highly significant and positive correlation with maximum and minimum temperature. Mealybug population had nonsignificant negative correlation with rainfall. This was well demonstrated by Koli (2003) who reported that mealybugs on grapes showed non significant negative correlation with rainfall.

\section{References}

Babu, T.R. and Azam, K.M. 1989. Biological control of grape mealybug, Maconellicoccus hirsutus (Green). J. Plant Protection Sci., 17(4): 123-126.

Balikai, R.A. 1999. Seasonal incidence of grapevine mealybug in north Karnataka. Insect Environ., 4(4): 148-149.

Fletcher, T.B. 1919. Report of the imperial entomologist. Scientific Report of Agri. Res. Institute, Pusa (India) for 1918-19, pp. 86-103.

Garcia-Alvarez, N.C., Urias-Lopez, M.A., Hernandez-Fuentes, L.M., Osuna-Garcia, J.A., Medina-Torres, R. and Gonzalez-Carrillo, J.A. 2014. Seasonal distribution and reproductive potential of the pink hibiscus mealybug (Hemiptera: Pseudococcidae) in Nayarit, Mexico. Revista mexicana de ciencias agricolas. 5(1): 5-16.

Koli, H.R. 2003. Seasonal incidence and management of grape mealybug, Maconellicoccus hirsutus (Green). M.Sc. (Ag.) Thesis. Mahatma Phule Krishi Vidhyapeeth, Rahuri, Maharashtra (India).

Kulkarni, N.S., Sawant, S.D. and Adsule, P.G. 2008. Seasonal incidence of insect pests on grapevine and its correlation with weather parameters. Acta Horticulturae, (ISHS). 785: 313-320.

Maheshkumar, K., Balikai, R.A. and Venkates, H. 2009. Seasonal incidence of grape mealybug, Maconellicoccus hirsutus (Green) and its relation with weather parameters. Pest Manage. Horticultural Ecosystems, 15(1): 916.

Mani, M., Thontadarya, T.S. 1987. Population dynamics of the mealybug Maconellicoccus hirsutus (Green) and its natural enemies in the grapevine ecosystem. J. Biol. Control, 1: 9397.

Mani, M. 1989. A review of the pink mealybug, Maconellicoccus hirsutus. Insect Sci. Appli., 10: 157-167.

Mani, M., Kulkarni, N.S., Banerjee, K. and Adsule, P.G. 2008. Pest management in grapes. National Research Centre on Grapes, Extension Bull., 2: 44.

Manjunath, T.M. 1985. India-Maconellicoccus hirsutus on grapevine. FAO Plant Protection Bull. J., 33(2): 74.

Murthy, G.R. and Babu, T.R. 1996. Seasonal fluctuations of mealybug population on custard apple and grape. J. Res. APAU, 24(12): 87-91.

Tandon, P.L. and Verghese, A. 1994. Present status of insect and mite pests of grapes in India. Drakshavritta: 149-157.

Tejkumar, S., Ahmed, A.M. and Dhramaraju, E. 1977. Occurrence of the mealybug, Pseudococcus spp. A serious pest of grapevine around Hyderabad. Indian J. Entomol., 39: 189-190.

\section{How to cite this article:}

Raghuraman Angu, A., C. Narendra Reddy, D. Anitha Kumari and Ramesh, S. 2017. Seasonal Incidence of Mealybug, Maconellicoccus hirsutus (Green) on Grape. Int.J.Curr.Microbiol.App.Sci. 6(2): 1629-1635. doi: http://dx.doi.org/10.20546/ijcmas.2017.602.181 
Int.J.Curr.Microbiol.App.Sci (2017) 6(2): 1629-1635 